\title{
Modelling the effect of temperature changes on plant life-form distribution across a treeline ecotone in the tropical Andes
}

\author{
Alberto Arzac, Luis D. Llambí, Raphael Dulhoste, José M. Olano and \\ Eulogio Chacón-Moreno
}

\section{QUERY SHEET}

This page lists questions we have about your paper. The numbers displayed at left are hyperlinked to the location of the query in your paper.

The title and author names are listed on this sheet as they will be published, both on your paper and on the Table of Contents. Please review and ensure the information is correct and advise us if any changes need to be made. In addition, please review your paper as a whole for typographical and essential corrections.

Your PDF proof has been enabled so that you can comment on the proof directly using Adobe Acrobat. For further information on marking corrections using Acrobat, please visit http://journalauthors.tandf.co.uk/production/acrobat.asp; https://authorservices.taylorandfrancis.com/how-to-correct-proofs-with-adobe/

The CrossRef database (www.crossref.org/) has been used to validate the references. Changes resulting from mismatches are tracked in red font.

\section{AUTHOR QUERIES}

Q1 Please note that the ORCID for Alberto Arzac has been created from information provided through CATS. Please correct if this is inaccurate.

Q2 Please provide missing Department for the affiliation.

Q3 Abstract must be maximum of 200 words long. Please check.

Q4 Please check whether the word "Program" is used in the computing context; if not, please change it to "programme" here and in subsequent instances if any.

Q5 The funding information Inter-American Institute for Global Change Research (IAI) provided has been checked against the Open Funder Registry and we failed to find a match. Please confirm if the Funding section is accurate and also confirm the funder name Inter-American Institute for Global Change Research (IAI).

Q6 The funding information Russian Ministry of Education provided has been checked against the Open Funder Registry and we failed to find a match. Please confirm if the Funding section is accurate and also confirm the funder name Russian Ministry of Education.

Q7 The funding information "Inter-American Institute for Global Change Research (IAI", "the Russian Ministry of Education Post-doctoral" and "Russian Ministry of Education" provided has been checked against the Open Funder Registry and we failed to find a match. Please confirm if the Funding section is accurate and also confirm the funder name "Inter-American Institute for Global Change Research (IAI", "the Russian Ministry of Education Post-doctoral" and "Russian Ministry of Education".

Q8 The disclosure statement has been inserted. Please correct if this is inaccurate.

Q9 Please provide missing publisher location for the “Anderson et al., 2011” references list entry.

Q10 The CrossRef database (www.crossref.org/) has been used to validate the references. Mismatches between the original manuscript and CrossRef are tracked in red font. Please provide a revision if the change is incorrect. Do not comment on correct changes.

Q11 Please provide missing publisher location for the “Arzac, 2008” references list entry.

Q12 Please provide missing publisher location for the "Chacón-Moreno, 2007” references list entry.

Q13 Please provide missing Publisher location for the "Holtmeier, 2009" references list entry.

Q14 Please provide missing publisher name/ Publisher location for the "ITC-ILWIS, 2001" references list entry.

Q15 Please provide missing page number for the "Llambí et al., 2014” references list entry. 
Q16 Please provide missing publisher location for the "Santaella, 2007" references list entry.

Q17 Please provide missing Publisher location for the "Wolfe, 1979" references list entry.

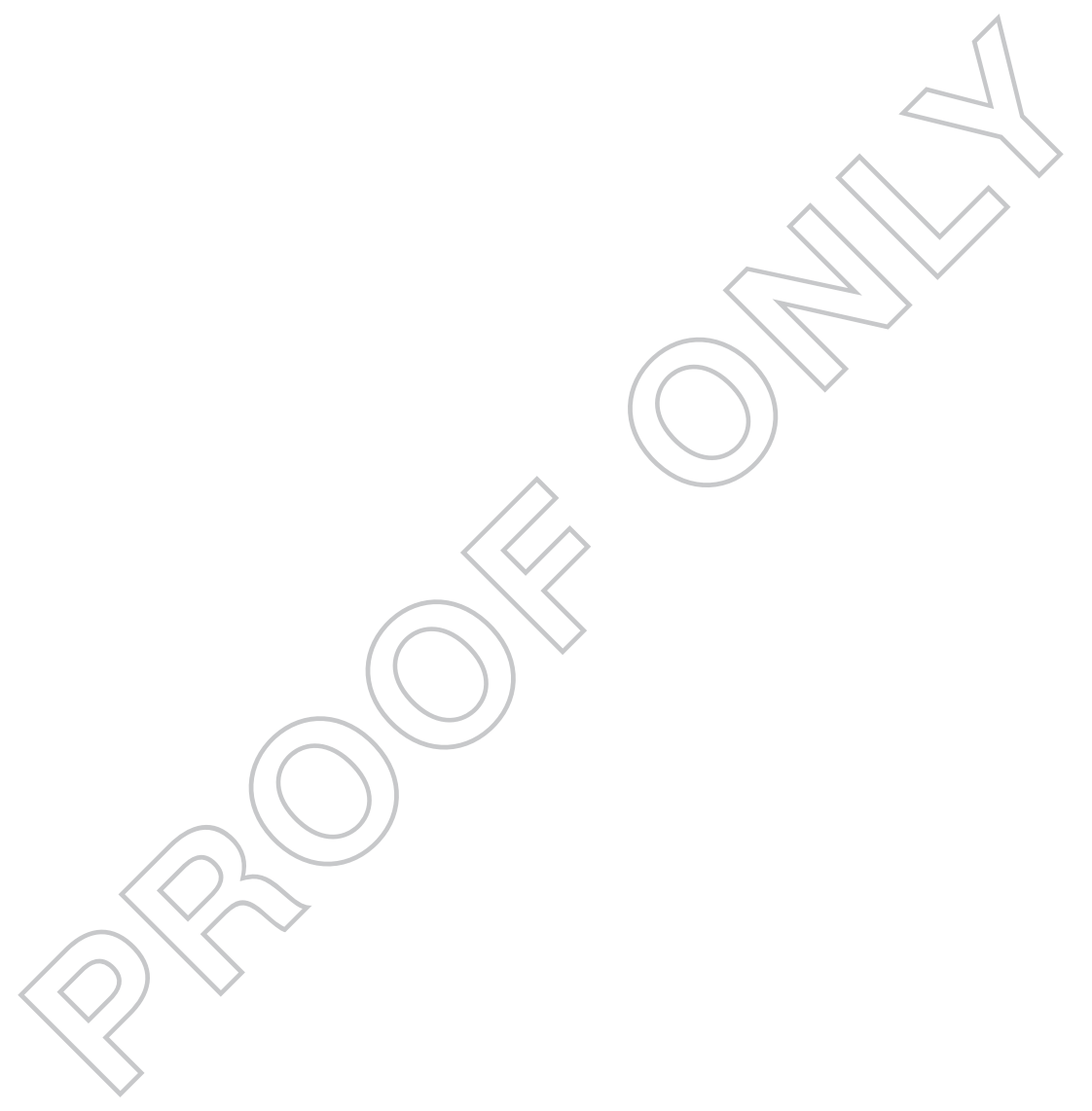




\title{
Modelling the effect of temperature changes on plant life-form distribution across a treeline ecotone in the tropical Andes
}

\author{
Alberto Arzac $\left(\mathbb{D}^{a}\right.$, Luis D. Llambíb, Raphael Dulhoste ${ }^{b, c}$, José M. Olano ${ }^{d}$ and Eulogio Chacón-Moreno ${ }^{b}$ \\ aInstitute of Ecology and Geography, Siberian Federal University, Krasnoyarsk, Russia; 'bnstituto de Ciencias Ambientales y Ecológicas \\ (ICAE), Facultad de Ciencias, Universidad de los Andes, Mérida, Venezuela; 'AEESP Saint-Genès La Salle, Bordeaux, France; ${ }^{d}$ Área de \\ Botánica, Departamento de Ciencias Agroforestales, Escuela Universitaria de Ingenierías Agrarias, iuFOR-Universidad de Valladolid, \\ Soria, España
}

\section{ABSTRACT}

Background: Classifying plant species from the high tropical Andes into distinct plant life forms (PLF) can provide a more functional understanding of tropical treeline dynamics. However, little is known about the potential response of different PLFs to climate warming. Aims: The objective of this work was to evaluate the response of PLFs to environmental conditions above the upper montane forest in the Venezuelan Andes and forecast their potential distribution under warming scenarios based on habitat suitability models.

Methods: We classified the plant species present above the forest line into nine PLFs including trees, shrubs, tussock grasses and caulescent rosettes, analysed and modelled their current distribution using Canonical Correspondence Analysis and non-linear multiple regressions and forecasted their potential distribution under warming scenarios (RCP4.5, RCP6.0, and RCP8.5). We used anatomical leaf traits for shrubs and caulescent rosettes to refine their potential responses to climate change.

Results: Tree cover sharply decreased with increasing elevation, while the distribution of shrubs and caulescent rosettes at higher elevations differed depending on their leaf traits. Projections suggested an upslope shift of all PLFs as a response to warming and an increase in tree cover.

Conclusions: The analysis of the distribution of PLFs, by linking different plant adaptive strategies to topography/climate, allowed projecting changes in vegetation physiognomy in response to warming. Projections of a moderate increase in tree cover in the grassland páramo did not indicate the formation of closed forests above the current upper forest line.

\section{ARTICLE HISTORY}

Received 18 December 2017

Accepted 8 August 2019

\section{KEYWORDS}

Climate change; elevation gradient; habitat suitability models; grassland páramo;

plant life-forms; upper montane forest

\section{Introduction}

The tropical Andes constitute the largest tropical mountain region worldwide, harbouring more than 20,000 endemic plant species (Myers et al. 2000; Young et al. 2002; Swenson et al. 2012) and providing critical ecosystem services such as carbon storage and water regulation (Price 2003; Harden et al. 2013; Molina et al. 2015; Hribljan et al. 2016, 2017). However, the dynamics and structure of the ecosystems are being increasingly affected by land use 40 (Young 2009; Feeley and Silman 2010; MathezStiefel et al. 2017) and climate (Young and León 2007; Anderson et al. 2011; Tovar et al. 2013). Moreover, future climate projections suggest potential species loss in the tropical Andes (Ramirez45 Villegas et al. 2014; Báez et al. 2016).

In the tropical Andes, the transition between the upper montane forest and grassland páramo (treeline ecotone) is a zone of particular interest due its outstanding species and functional diversity (Bader et al. 2007a; Ramírez et al. 2009; Hofstede et al. 2014; Peters et al. 2014; Llambí 2015). The treeline is characterised by clear physiognomic changes with elevation, where tussock grasses, small sclerophyllous shrubs and caulescent rosettes replace trees and tall shrubs (Sklenář and Jørgensen 1999; Arzac et al. 2011; Sarmiento Pinzón and León Moya 2015). Reported temperature increases of up to $0.4-0.5^{\circ} \mathrm{C}$ per decade above $3000 \mathrm{~m}$ a.s.l. in the tropical Andes (Vuille and Bradley 2000; Vuille et al. 2018) demand a better understanding on how changes in environmental conditions along topographic gradients influence vegetation distribution at the Andean treeline. However, to date there is little information on this topic, as most treeline studies globally have concentrated on extra-tropical regions (Holtmeier and Broll 2005; Holtmeier 2009; Körner 2012).

Evidence from permanent plots established in the 1990s indicates an upward migration and thermophilisation of tree communities in Andean upper 
70 montane forests (Duque et al. 2015; Fadrique et al. 2018). The displacement of the main vegetation types because of climate warming has also been forecasted by models based on topographic/climatic variables (Bader and Ruijten 2008; Tovar et al.

75 2013). However, it is species, and not whole plant communities, that respond to climate change on the bases of their adaptive strategies, inducing the assembly of novel non-analogue communities (Williams and Jackson 2007). Hence, given the out80 standing species and functional diversity characteristic of tropical treeline vegetation, an approach based on functional traits would be useful to model the patterns of change in plant community structure in response to climate.

High Andean plant species have been classified into architectural types or plant life forms (PLFs) using readily identifiable morphological traits (Hedberg 1964; Hedberg and Hedberg 1979; Wolfe 1979; Ramsay and Oxley 1997). The use of PLFs is as

90 a functionally meaningful strategy to represent spatial and temporal changes in the distribution of plant species, linking the adaptive characteristics expressed in a PLF with environmental gradients (Furze et al. 2013). Analysing the current distribution of PLFs at a landscape scale, and potential changes in it, may be used to assess and compare treeline dynamics under warming scenarios between regions with widely contrasting floristic composition but similarities in vegetation structure

100 (e.g. Scherrer and Körner 2011). Some previous studies have analysed the distribution of PLFs along elevation gradients in the tropical Andes (e.g. Balslev and de Vries 1989; Ramsay and Oxley 1997; Arzac et al. 2011). However, the potential 105 response of vegetation and life-form structure to climate change scenarios remains unexplored.

In this work, we analysed the spatial distribution of dominant PLFs in a relatively undisturbed landscape above the continuous limit between upper 110 montane forest and grassland páramos and assessed their potential response to climate warming. We expanded the basic PLF classification system of Hedberg (1964) by including trees and forbs, which are important components structuring

115 vegetation across the treeline. Moreover, we explored the effect of adaptive traits that can influence leaf thermal/radiation balance (i.e. pubescence and leaf size, see Cuatrecasas 1968; Vareschi 1992), in modulating the spatial distribution of caulescent rosettes and sclerophyllous shrubs, which constitute dominant PLFs above the treeline (Arzac et al. 2011; Sarmiento Pinzón and León Moya 2015).
We characterised the current distribution of PLFs in relation to local topographic variables (slope orientation and inclination) along an elevation/thermal gradient with low anthropogenic impact and hypothesised that: (1) anatomical leaf attributes would be an important factor in the distribution of PLFs along the elevation/thermal gradient; and (2) warming scenarios would have a differential impact on the potential distribution of PLFs, expressed as elevational shifts linked to slope orientation, modifying landscape vegetation physiognomy above the treeline.

\section{Materials and methods}

\section{Study area}

We sampled six transects along an elevation gradient of $250 \mathrm{~m}$ ranging from 3300 to $3550 \mathrm{~m}$ a.s.l. (Figure 1(a)), above the upper montane forest in the Sierra Nevada mountain range, Mérida, Venezuela, near La Aguada station of the Mérida cable car system $\left(8^{\circ} 33^{\prime} 54.56^{\prime \prime} \mathrm{N}, 71^{\circ} 5^{\prime} 22.65^{\prime \prime} \mathrm{W}\right)$. The area is within the limits of the Sierra Nevada National Park, created in 1952, where land-use has been restricted in the last decades to very lowdensity livestock grazing (density below 0.1 animals $\mathrm{ha}^{-1}$ ) without the use of fires. A diachronic analysis of land-cover in the area, comparing aerial photographs from 1952 and 1998, has shown no evidence of vegetation cover changes related to agriculture or the creation of secondary pastures (Santaella 2007), indicating the current treeline position in the region has not been directly altered by land-use change, at least in the last 60 years.

The climate in the region is characterised by two periods of high rainfall (April-June and OctoberNovember). A dry period occurs between January and March; during this time night frosts may occur (reaching minima of $-3^{\circ} \mathrm{C}$ ). Mean annual temperature at the upper forest line is $7.1^{\circ} \mathrm{C}$ and the mean total annual precipitation is $1811 \mathrm{~mm}$ (data from La Aguada meteorological station, $3452 \mathrm{~m}$ a.s.l.).

The vegetation of the upper montane forest $(3200-3300 \mathrm{~m})$ is dominated by Psammisia penduliflora (Dunal) Klotzsch, Miconia tinifolia Naudin and Libanothamnus neriifolius Ernst. A grassland páramo appears above (over $3300 \mathrm{~m}$ asl), dominated by the tussock grass Calamagrostis effusa (Kunth) Steud. and scattered woody species (small trees and tall shrubs such as Cybianthus marginatus (Benth.) Pipoly, Hesperomeles ferruginea (Pers.) Benth., Diplostephium venezuelense Cuatrec., and Senecio pachypus Greenm Trans. Vegetation at higher 


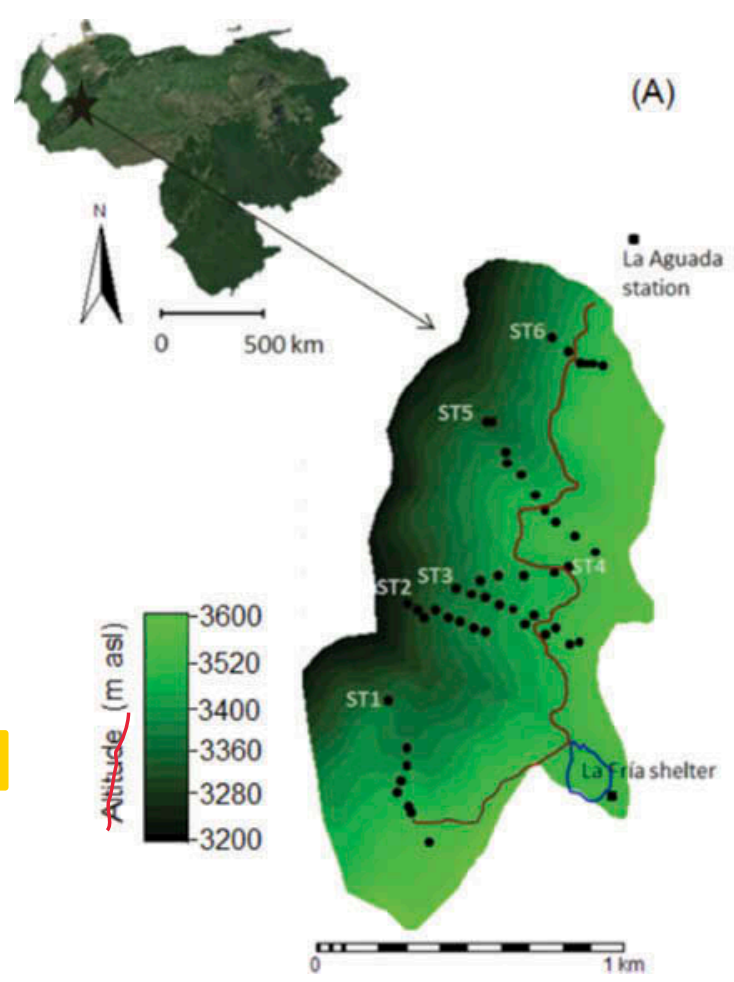

(B)

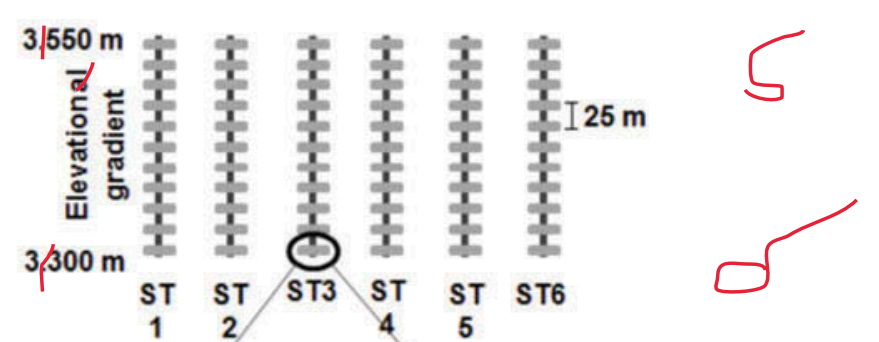

Figure 1. Location of the study area in the Sierra Nevada mountain range, Venezuelan Andes. (a) Digital elevation model of the sampling site showing the distribution of sampling transects (ST1-ST6). (b) Schematic distribution of sampling units along the sampling transects; grey rectangles represent the position of sampling units. (c) Schematic design of sampling units; each black square indicates a sampling point.

elevations is dominated by caulescent rosettes (mainly Espeletia shultzii Wedd. and Ruilopezia atropurpurea (A.C.Sm.) Cuatrec.), and smaller sclerophyllous shrubs (e.g. Hypericum laricifolium Juss.); see Ramírez et al. (2009) and Llambí et al. (2014) for further details.

\section{Plant life-form (PLF) selection and field sampling}

180 We complemented the life forms system of tropical alpine vegetation (caulescent rosettes, sclerophyllous shrubs, cushion plants, tussock grasses and acaulescent rosettes) of Hedberg (1964) by including trees and forbs as additional growth forms.

185 Based on morphological characteristics that could influence the leaf energy balance, we subdivided caulescent rosettes into pubescent and nonpubescent and sclerophyllous shrubs into leptophyllous and nanophyllous types (Rada et al.

190 1985; Meinzer et al. 1994; Azócar and Rada 2006). In total, nine PLFs were identified: acaulescent rosettes (AR), caulescent pubescent rosettes (CPR), caulescent non-pubescent rosettes (CNR), leptophyllous sclerophyllous shrubs (LSS, leaf size

$\left.195<0.2 \mathrm{~cm}^{2}\right)$, nanophyllous sclerophyllous shrubs (NSS, $0.2-2 \mathrm{~cm}^{2}$ ), microphyllous sclerophyllous shrubs (MSS, 2-20 $\mathrm{cm}^{2}$ ), tussock grasses (TG), forbs $(\mathrm{F})$ and trees $(\mathrm{T})$.
During July and August 2007 six transects were established over an elevation gradient from the upper natural limit of montane forest (3300 $\mathrm{m}$ a.s.l.) to the grassland páramo (3550 $\mathrm{m}$ a.s.l.). The upper limit of the transects was established at the elevation at which no forest trees were observed within the páramo matrix (isolated or in clumps). Each replicate transect was separated from the other by 100 to $500 \mathrm{~m}$ in the direction perpendicular to the slope (to increase independence between replicate transects). Two transects were located on the dominant slope orientations within the area (north, north-west, and west). In each transect, 10 sampling units (consisting of two 10-m-long parallel lines separated by $2 \mathrm{~m}$ ) were placed, separated by $25 \mathrm{~m}$ in elevation (Figure 1(b)). The cover of selected PLFs was measured using the point quadrat method (Greig-Smith 1983), using 50 sampling points per line, each separated by $20 \mathrm{~cm}$ (Figure 1(c)). For each sampling unit geographical position, elevation, slope orientation and slope inclination were recorded.

\section{PLF distribution along the elevation gradient}

The relationship between the abundance (cover) of PLFs and environmental factors (elevation, slope orientation and slope inclination) was evaluated by canonical correspondence analysis (CCA). The 
225 elevation distribution optimum for the studied PLFs along the gradient was determined by the weighted arithmetic mean and the amplitude of distribution by the weighted standard deviation (or tolerance), combining the data for the six trans-

230 ects (see Legendre and Legendre 2012 for details). Finally, regression models based on sigmoidal and Gaussian response curves or a combination of both were used to analyse the response of PLF coverabundance to the environmental factors. Here, we used as replicates each of the six transects sampled (more than $100 \mathrm{~m}$ of separation), which were distributed along the study area to attempt to obtain an adequate representation of the distribution of PLFs across the treeline in this sector (with an observation window of ca. $3 \mathrm{~km}^{2}$ ).

\section{PLF distribution models and warming scenarios}

We modelled the spatial distribution of PLF's under current climate conditions by producing habitat suitability models (Dirnböck et al. 2003), in response to elevation/temperature and slope orientation and their interaction. An environmental predictor was obtained through non-linear multiple regression models (Guisan and Zimmermann 2000) analysing the cover of each PLF (dependent variable) as

250 a function of environmental factors (independent variables). This approach allowed a smooth integration of the obtained environmental predictor variables into a geographical information system (Chacón-Moreno 2007; Chacón-Moreno et al. 2007). Whereas the CCA was used to analyse the relation between environmental variables and changes in vegetation community structure when all nine PLF are considered together, non-linear multiple regression regressions evaluated them one by

260 one, allowing the modelling of PLF spatial distribution and their potential changes in temperature warming scenarios.

The geographical information used for the spatial models (elevation and slope orientation) was obtained from a digital elevation model (DEM) produced by digitalising the 5941-I-SE contour line map of the area (Venezuelan National Cartography; scale 1:25,000). Habitat suitability models were built with the ITC-ILWIS 3.8 software

270 (ITC-ILWIS 2001). Models were developed for the most abundant PLFs (CPR, CNR, LSS, TG and T). Each pixel of the distribution maps represents a probabilistic cover value for a particular PLF.

To forecast potential PLF distribution patterns the habitat suitability models for current distribution (including elevation and slope orientation) in which elevation was replaced by temperature values, using the linear regression model: temperature $=27.98-0.006 \mathrm{x}$ elevation (Suárez del Moral and Chacón-Moreno 2011). This equation was produced from linear interpolations of 89 meteorological stations in Mérida state, monitored by the Ministry of Environment and Natural Resources (MARN) and the Universidad de Los Andes (see Suárez del Moral and Chacón-Moreno 2011 for further details).

The selection of future warming scenarios was based on projections from climate change models used in the Fifth Assessment Report of the Intergovernmental Panel on Climate Change (AR5) (IPCC 2013). Thus, three Representative Concentration Pathways (RCP) scenarios were selected, identified by the twenty-first century peak or stabilisation value of the Radiative Forcing: RCP4.5, RCP6.0, and RCP8.5 (IPCC 2013). We used the projections for temperature expressed as anomalies over the mean temperature values for the reference period 1986-2005, analysed in two periods of 30 years (period 2025 to 2055 , focused on the year 2040, and period 2045 to 2075, centred on the year 2060; Table 1).

\section{Results}

\section{PLF distribution along the gradient and habitat suitability models}

PLF distribution was structured along the elevation gradient (Figure 2), with each PLF occupying a different elevation (and temperature optimum), although with some overlapping in their distribution amplitude ( $\pm 60 \mathrm{~m}$ on average), with CPR and NSS showing the lowest and highest amplitude values $( \pm 36 \mathrm{~m}$ and $\pm 80 \mathrm{~m}$ respectively). Trees occupied the lowest elevation at the bottom of the gradient $(3300 \pm 69 \mathrm{~m}$ a.s.l.; corresponding to a mean temperature of $8.2^{\circ} \mathrm{C}$ ), while LSS and AR were found at the highest elevation at the top

Table 1. Temperature increments for the different Representative Concentration Pathway (RCP) scenarios for 2040 and 2060 at the Sierra Nevada de Mérida, Venezuelan Andes.

\begin{tabular}{lccc}
\hline & \multicolumn{2}{c}{ Temperature difference in relation to the period } \\
& & \multicolumn{2}{c}{ 1986-2005 $(\mathrm{K})$} \\
\cline { 3 - 4 } & & 2040 & 2060 \\
\hline RCP & RCP4.5 & 0.7 & 0.9 \\
& RCP6.0 & 1.3 & 1.9 \\
RCP8.5 & 1.8 & 2.6 \\
\hline
\end{tabular}




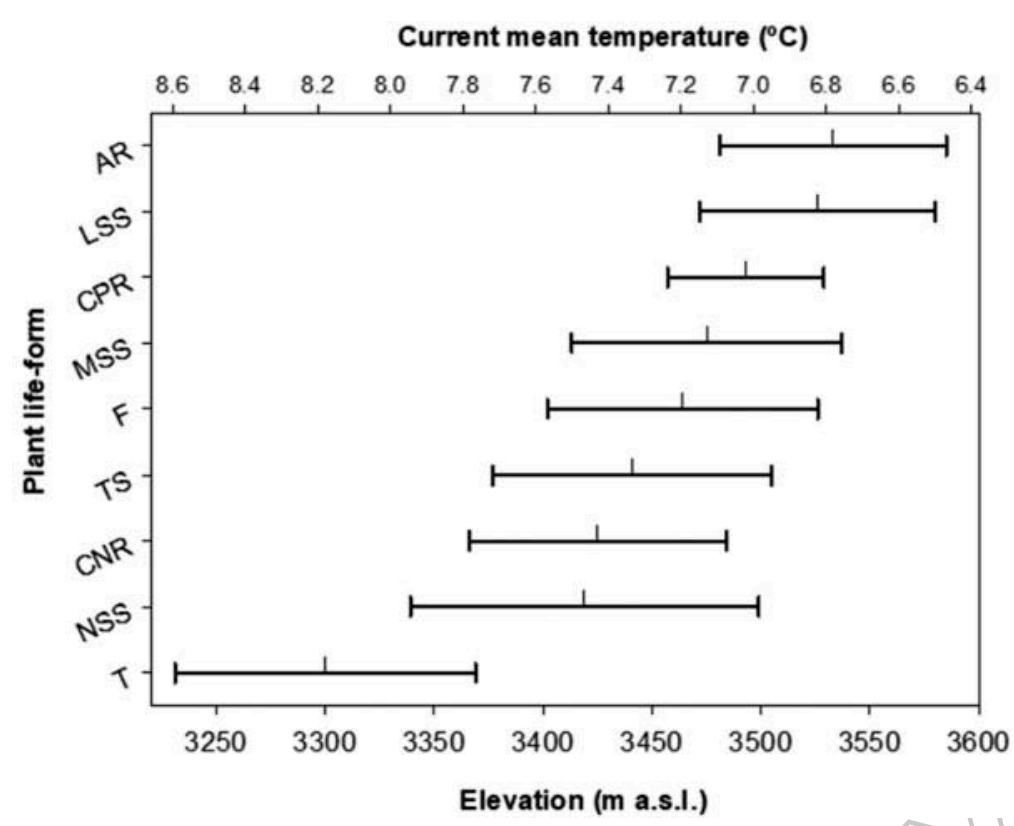

Figure 2. The distribution of PLFs along the elevation - temperature gradient, indicating the elevation optimum, amplitude of distribution and thermic gradient. Vertical lines indicate the elevation optimum and horizontal lines show the amplitude of distribution. T, trees; NSS, nanophyllous shrubs; CNR, caulescent non-pubescent rosettes; TG, tussock grasses; F, forbs; MSS, microphyllous shrubs; CPR, caulescent pubescent rosettes; LSS, leptophyllous shrubs and AR, acaulescent rosettes.

$(3526 \pm 54 \mathrm{~m}$ a.s.l. and $3533 \pm 52 \mathrm{~m}$ a.s.l. respectively; $\left.6.8^{\circ} \mathrm{C}\right)$. The thermal amplitude of the gradient ranged from 8.2 to $6.7^{\circ} \mathrm{C}$ (Figure 2), NSS, CNR,

320 TG, F, MSS and CPR occupied successive positions along the elevation/thermal gradient (Figure 2).

Leaf morphological characteristics in caulescent rosettes and sclerophyllous shrubs appeared to be related with their spatial distribution in the landscape. Thus, CPR, LSS and MSS showed elevation optima higher than CNR (rosettes without leaf pubescence) and NSS. At their optimum elevation distribution, TG reached the highest cover values (84\%), while other PLFs showed maximum cover values of less than $30 \%$ at their optimum distribution.

Canonical correspondence analysis (CCA) showed that slope orientation and elevation were the most significant factors evaluated related to the distribution of PLFs (Figure S1). The CCA ordination (over the two main axes comprising $60.0 \%$ and $29.9 \%$ of overall variance) suggested that CPR and AR were associated with the highest elevations whereas trees occupied the opposite extreme of the ordination diagram. Slope orientation appeared

340 to be related with the distribution of caulescent rosettes and shrubs, with CNR being associated with north-facing slopes, while CPR, AR, NSS and LSS showed higher cover in north-west- and west-facing slopes (see Figure S1 for further details); local slope inclination was not a statistically significant factor related to the distribution of PLFs.
Regression models indicated a significant effect of both elevation and slope orientation on the cover of all PLFs, with $\mathrm{R}^{2}$ values ranging between 0.38 and $0.77(P<0.001)$, with the lowest explained variance for non-pubescent rosettes $\left(\mathrm{R}^{2}=0.28\right.$; $P<0.01$; Table S1).

Habitat suitability models under current climate conditions for the selected PLFs (i.e. CPR, CNR, LSS, NSS, TG and T) showed differences in the spatial distribution of cover values for each of them within the study site (Figure 3(a-e)). Trees exhibited higher relative cover values $(8-25 \%)$ at lower elevations, on north-west-facing slopes (Figure 2(a)). Tussock grasses had the highest cover values (60-90\%) and a wide elevation distribution across the gradient, with a slightly higher cover on north-facing slopes (Figure 3(b)). Habitat suitability models predicted a higher abundance of LSS towards the top of the gradient on west-facing slopes (Figure 3(c)), with cover values between $8-15 \%$, in comparison with NSS with a lower elevation range (data not shown). The presence/ absence of pubescence in studied species of caulescent rosettes also appeared to be related to their distribution. Caulescent rosettes with pubescent leaves (CPR) showed cover values (between 10 and $20 \%$ ) at higher elevations, mostly in westfacing slopes (Figure $3(\mathrm{~d})$ ), while those without pubescence (CNR) showed their higher cover values (between 4 and 16\%) at mid-elevations on north-facing slopes (Figure 3(e)). 


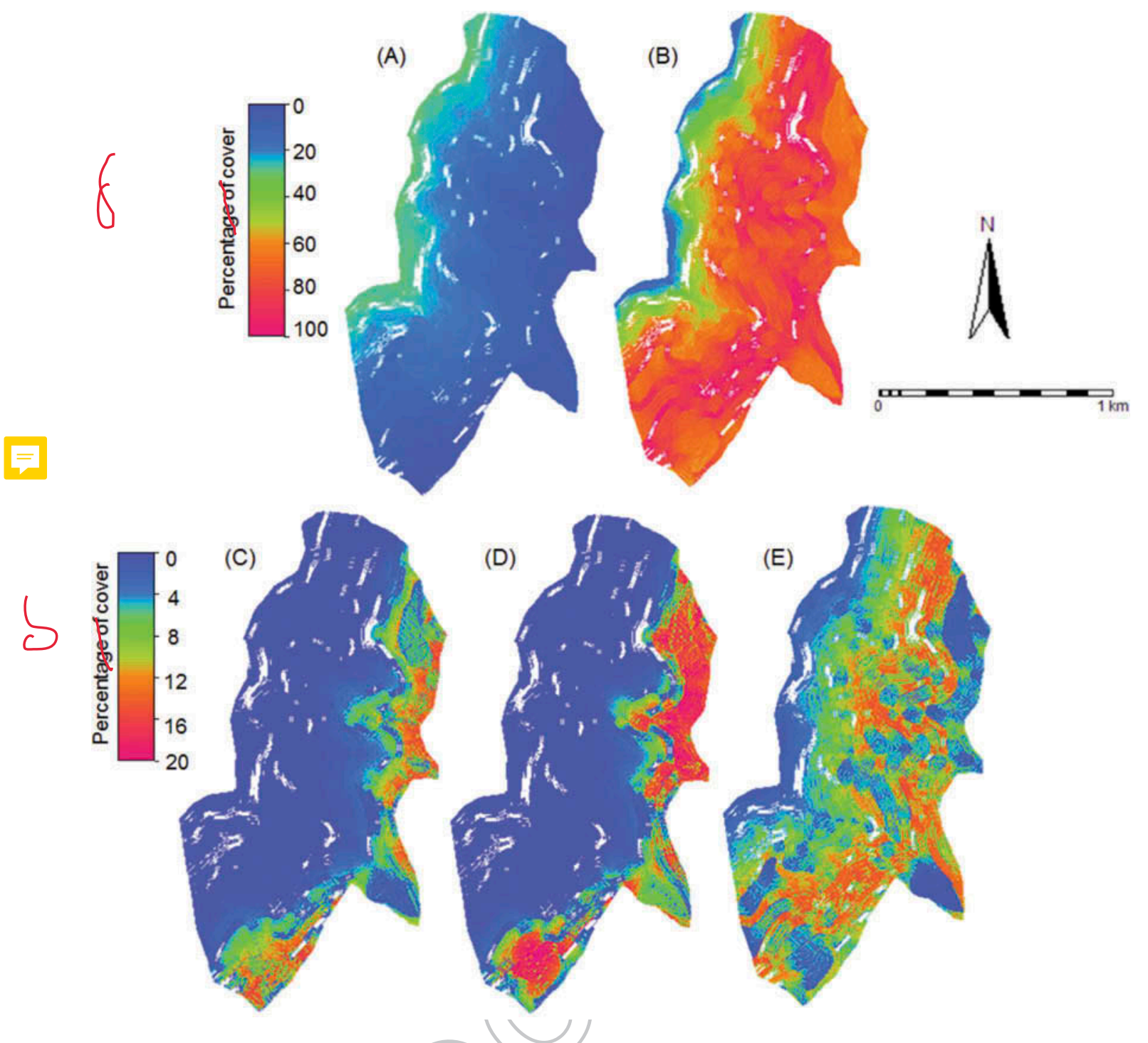

Figure 3. Spatial distribution models showing the percentage of surface cover for the selected plant life-forms at the sampling site, Sierra Nevada mountain range, Venezuela, under current climate conditions. (a) Trees, (b) tussock grasses, (c) nanophyllous sclerophyllous shrubs, (d) leptophyllous sclerophyllous shrubs, (e) Caulescent pubescent rosettes and (f) caulescent nonpubescent rosettes. Pixels in the habitat suitability models represent a probabilistic cover value for a particular PLF. Colours represent the cover percentage from blue (low cover) to red (high cover).

\section{Habitat suitability models under warming scenarios}

Projections based on elevation and slope orientation considering the increments of mean annual temperature under different warming scenarios, suggested an upslope migration for all PLFs analysed, with conse385 quent changes in the configuration and structure of vegetation above the upper montane forest by the years 2040 and 2060, independently of the scenario considered (RCP4.5, RCP6.0 and RCP8.5). Projections suggested an elevational advance of 390 trees (Figure 4(a-f)), expanding their current distribution limit and increasing their cover above the current forest line. The rate of expansion was related to the magnitude of the temperature increase, reaching cover values of $30-40 \%$ in the middle of the gradient ( $3450 \mathrm{~m}$ a.s.l.) for the scenario RCP6.0 by the year 2040 (Figure 4(c)) and close to $40 \%$ at the top of the gradient $(3550 \mathrm{~m}$ a.s.l.) for the warmest scenario RCP8.5 by the year 2060 (Figure 4(f)). Projections for tussock grasses (Figure 4(g-l)) suggested a marked decrease in their cover and relative importance above the forest line. Under the scenario RCP4.5, TG cover would be reduced in the lower elevations to $20-40 \%$ by the years 2040 and 2060 , respectively (Figure $3(\mathrm{~g}$ and $\mathrm{h})$ ). This trend was more pronounced for the scenario RCP6.0, for which the cover could reach values around $40 \%$ at the top of the gradient (3400-3550 $\mathrm{m}$ a.s.l.) by the year 2060 (Figure 4(j)). In the scenario RCP8.0, projections suggest that by the year 2060 TG cover could be lower than $20 \%$ in the whole area, implying an important change in vegetation physiognomy, currently dominated by $\mathrm{TG}$. 

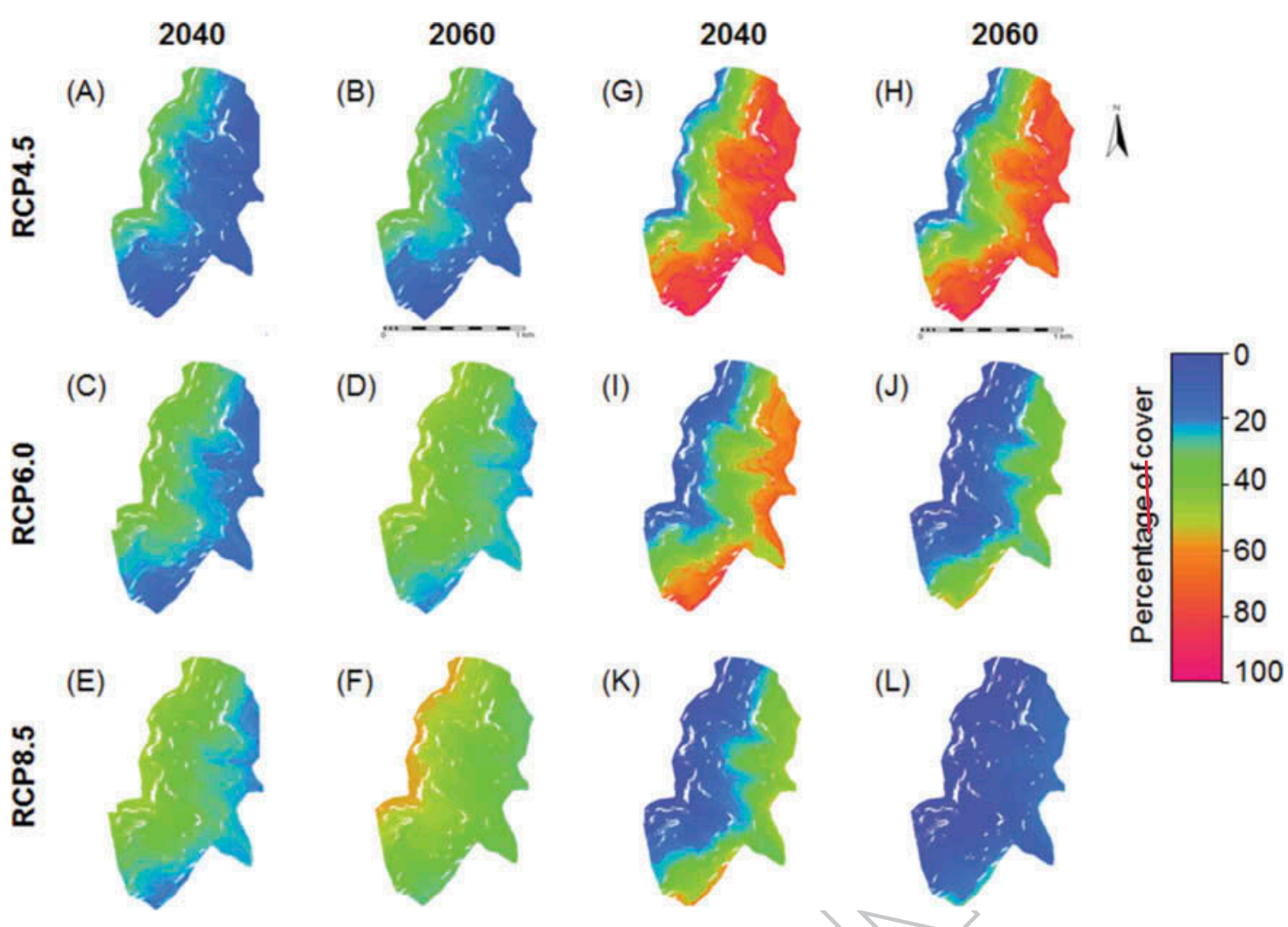

Figure 4. Cover distribution models for tress (a-f) and tussock grasses ( $g-1)$ under climate change scenarios for the study site in the Sierra Nevada de Mérida, Venezuela. The Representative Concentration Pathway (RCP) and the future time periods are indicated. Pixels in the habitat suitability models represent a probabilistic cover value for a particular PLF. Colours represent the percent cover from blue (low cover) to red (high cover).

Caulescent non-pubescent rosettes, currently occupying lower elevations close to the upper montane forest limit, may shift upslope with a significant decrease in their coverage by the year 2060 under the scenario RCP4.5 (Figure 5(b)). By the year 2040 and the scenario RCP6.0, CNR would only occur at the top of the gradient with cover values below $8 \%$ 420 (Figure 5(c)). On the other hand, caulescent pubescent rosettes (Figure 5(g)) currently occupying a highest elevation, could reduce their cover to values lower than $4 \%$ by the years 2040 in the scenario RCP4.5 (Figure 5(g)) and absent thereafter.

425 In the rest of the scenarios considered, pubescent rosettes could be absent from the study site, thus moving to elevations above the current Andean treeline ecotone. Scenario RCP8.5 could imply the disappearance of both rosette life-forms within the $300 \mathrm{~m}$ above the current Andean treeline within the study area. Habitat suitability models under future warming scenarios for sclerophyllous shrubs suggested the displacement to higher elevations of LSS above the study area by the year 2040 even in 435 the scenario RCP4.5, with a cover value below $9 \%$ (Figure S2).

\section{Discussion}

Plant life form (PLF) distribution was associated with changes in elevation/mean temperature, with tussock grasses, caulescent rosettes and sclerophyllous shrubs replacing trees as the dominant PLF above the current forest limit. The distribution of shrubs and caulescent rosettes in relation to elevation and slope orientation was related to their leaf traits. Using habitat suitability models, we found that changes in temperature could modify the elevation distribution range of the dominant PLFs and the position of the Andean treeline under future warming scenarios, with a moderate increase in tree cover in the grassland páramo over the next decades without the formation of closed forests above the current upper montane forest line.

\section{Plant life-form distribution along the elevation/ thermal gradient}

Our results suggest that within an area with very low anthropogenic pressure at least during the last 70 years, the distribution of PLFs was strongly 


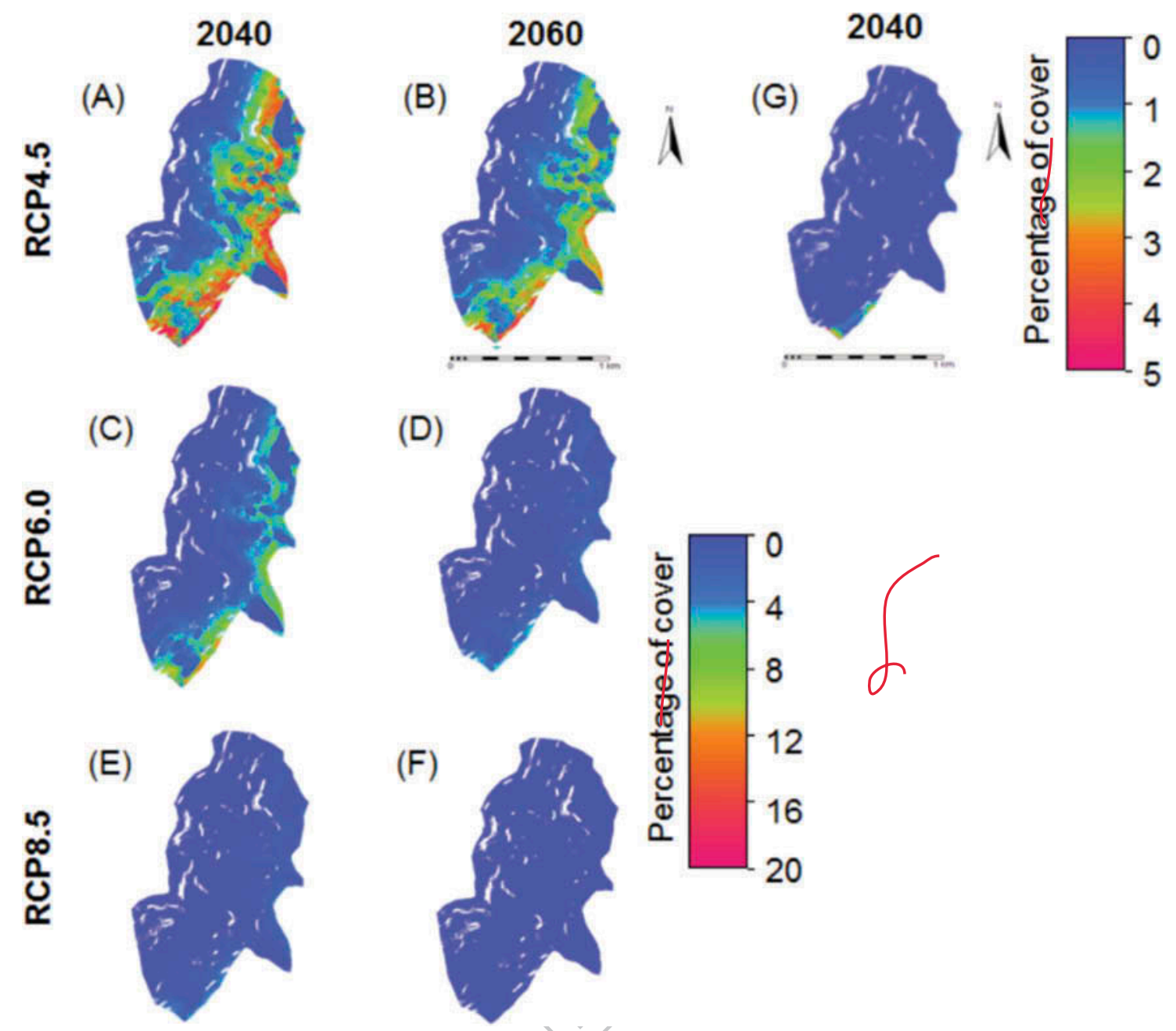

Figure 5. Cover distribution models of caulescent non-pubescent rosettes (a-f) and caulescent pubescent rosettes (only RCP4.5 by the year 2040 is shown, G) under climate change scenarios for the study site at the Cordillera de Mérida, Venezuelan Andean, Mérida State. The Representative Concentration Pathway (RCP) and the future time periods are indicated. Pixels in the habitat suitability models represent a probabilistic cover value for a particular PLF. Colours represent the percent cover from blue (low cover) to red (high cover).

related to topographic variables (elevation and slope orientation). Both factors interact to deter460 mine incident radiation and temperature regimes at the local scale. These results are supported by previous studies within the same study area (Ramírez et al. 2009; Llambí et al. 2014) and the Ecuadorian Andes (Keating 1999; Wille et al. 2002;

465 Bader et al. 2008; Bader and Ruijten 2008; Hofstede et al. 2014), documenting the relationship of species abundance and forest cover patterns across the tropical treeline. The thermal amplitude of the studied gradient (where trees are replaced by characteristic páramo PLF), ranged from 8.2 to $6.7^{\circ} \mathrm{C}$, corresponding with the mean growing season temperature range that defines the treeline globally (Körner 2012).

However, at local spatial scales PLFs distribution 475 patterns may be more complex, since other parameters associated with local topographic heterogeneity in mountain areas could also have an impact on plant distribution ranges through their effect on microhabitat conditions (Scherrer and Körner 2011; Frankin et al. 2013). This is indicated by the coefficient of determination of PLF response models to elevation and slope orientation $\left(\mathrm{R}^{2}\right.$ values ranged from 0.76 for trees to 0.28 for caulescent nonpubescent rosettes), which suggest the existence of unaccounted variation being associated with the distribution of PLFs. Although, slope inclination was not found to be a significantly related to the distribution of PLFs, a more detailed understanding of how changes in topography and vegetation cover modify local temperature regimes would be a key step for improving our capacity to model the spatial responses of vegetation to warming across the Andean treeline. Other local features such as the presence of rocky outcrops or biogenic microclimatic changes attributable to local plant cover could be important in influencing patterns of tree establishment above upper montane forest (see 
Llambí et al. 2013; Bueno and Llambí 2015). In addition, establishing a higher number of replicate

500 transects, distributed over a wider region could be important to obtain a more representative set of independent samples and to allow the validation of the exploratory models presented here against an independent data set.

505 A sharp decrease in the abundance of trees in the grassland páramo and a non-linear decrease in maximum tree sizes (Arzac 2008) with increasing elevation, appears to be linked to an increase in the abundance of small sclerophyllous shrubs and cau-

510 lescent rosettes (which are common elements of the grassland páramo). On the other hand, the fact that the highest tree cover-abundance values were found on north-west facing slopes (Figure 3(a)) might be related to lower incident radiation, which could decrease tree mortalities (e.g. by decreasing either photoinhibition or water stress). According to modelling results from Bader and Ruijten (2008), variability in Andean treeline elevation can be associated with slope orientation in Central Ecuador, which influences solar radiation loads.

Plant species inhabiting grassland páramos have developed adaptive mechanisms that allow them to tolerate high incident radiation and daily temperature amplitude (Squeo et al. 1991; Azócar and Rada 2006). Modifications in leaf structure (size and pubescence) might help to explain the contrasting distribution pattern observed within sclerophyllous shrubs (with larger leaf sizes being associated with a lower elevation optimum) and caulescent rosettes

530 (species with non-pubescent leaves showing a lower elevation optimum). The decrease in leaf area of sclerophyllous shrubs with elevation has been proposed as a drought resistance mechanism (Vareschi 1992; Ely and Torres 2003). In fact, the shrubs with the smallest leaf size (LSS) showed their optimum abundance at higher elevations on west-facing slopes, which had the highest incident radiation in our study site (Arzac 2008).

Leaf pubescence in caulescent rosettes can 540 strongly influence the leaf energy balance, reducing the absorption of solar radiation (Rada et al. 1985; Vareschi 1992; Meinzer et al. 1994; Azócar and Rada 2006). This mechanism might explain the higher abundance observed for pubescent rosettes (CPR) values towards the upper extreme of the gradient, on the west-facing slopes, which tend to show lower minimum temperatures but higher solar irradiance in the study area (Figure 3(e)), whereas non-pubescent rosettes (CNR) peaked at 550 lower elevations on north-facing slopes (with lower radiation loads, see Arzac 2008). In addition, CPR's show freezing avoidance strategies through the protection of organs by insulating structures (e.g. marcescent leaves) and supercooling (Rada et al. 1985; García-Varela and Rada 2003), allowing them to resist low minimum air temperatures.

\section{Forecasting PLF distribution under warming scenarios}

Our projections suggest an expansion of woody plants over the páramos just above the current treeline, increasing the density of trees and their elevation range, while tussock grasses and caulescent rosettes would decrease in abundance (Figures 4(g-l) and 5). The upslope extension projected for all life-forms as a response to warming is in accordance with observed upslope migrations of plants and animals in the Andes (e.g. Deutsch et al. 2008; Chen et al. 2009; Feeley et al. 2011; Feeley 2012; Morueta-Holme et al. 2015). However, there is a paucity of studies in the tropical Andes documenting tree species and vegetation shifts specifically at the treeline ecotone; and those available, indicate an upward response of the treeline in the last decades only in sites within protected areas with limited human impacts (Lutz et al. 2013; Rehm and Feeley 2015), as is the case in our study region (Santaella 2007).

The elevation shift might not necessarily be linear as parameters other than temperature can lead to azonal vegetation patterns, such as the presence of nearby water sources which provide a heterogeneous mosaic of micro-climatic conditions or water availability for tree growth (see Bush et al. 2010 results from the Central; Andes and Arzac et al. 2016; Arzac et al. 2018 for soil moisture in Mediterranean environments). Albeit the high annual precipitation in our study area $(1,811 \mathrm{~mm})$, low mean temperatures and a very short dry season might suggest that soil water availability is not a limiting factor, water availability could explain the higher elevations reached by forests in azonal areas associated with ravines and watercourses (which were excluded from our sampling transects).

Interestingly, even under the warmest scenario (RCP8.5), the simple modelling exercise carried out here indicates that tree cover would reach values of ca. $40-50 \%$ in the study area in the next decades (extending $300 \mathrm{~m}$ of elevation above the present continuous forest), but without the formation of a closed forest canopy. This agrees with an analysis of changes in vegetation cover in the same 
region between 1952 and 1998, which indicated an increase in tree densities at and above the treeline, rather than a clear elevation advance of closed forests over the páramo (Santaella 2007).

Previous studies in the Venezuelan and Ecuadorian Andes have shown that only some small tree and tall shrub species that dominate the upper montane forest edge (e.g. Cybianthus,

610 Diplostephium, Hesperomeles) can establish and reach adult sizes in the páramos outside upper montane forests (Bader et al. 2007b; Ramírez et al. 2009; Llambí et al. 2013). Some of these species (e.g. Diplostephium spp.) have a higher tol-

615 erance to the high radiation characteristic of open páramo environments than species dominating continuous forests (Bader et al. 2007b).

The limitations faced by forest trees to establish in open environments outside the forest canopy 620 may support the existence of positive feedback mechanisms which could stabilise the dynamics of the upper forest line in the tropical Andes (Bader et al. 2008). Facilitation by shrubs might play a role in seedling establishment outside of the forest by providing the necessary micro-climatic conditions (García-Cervigón et al. 2012; Cáceres et al. 2015; Ramírez et al. 2015). Different pieces of evidence suggest that this phenomenon may be important at the tropical treeline ecotone

630 (González et al. 2011; Llambí et al. 2013; Rehm and Feeley 2013; Bueno and Llambí 2015).

All of this would agree with scenarios (as the one suggested by our modelling exercise) in which the elevation advance of forest over the paramos is initiated by the establishment of individual pioneer trees outside the treeline border, prior to the formation of a closed canopy, facilitating the subsequent colonisation of other tree species dependent on the more favourable conditions within closed forests

640 (Rehm and Feeley 2013; Rehm et al. 2015). However, incorporating biotic interactions into treeline dynamics models would be necessary to evaluate how much of the variance can be explained by biotic vs abiotic drivers and their interactions.

\section{Limitations of the approach and challenges for further research}

Our approach is an exercise to evaluate changes in treeline structure and spatial dynamics using a non-taxonomic classification based on PLF, mor-

650 phological traits and simple habitat suitability models as a prospective tool. Further research is needed to widen the spatial extent of field sampling and validate the model with an independent data set and at wider spatial scales. However, the use of PLFs seems a promising approach to synthesise the response of individual species to environmental factors in highly diverse environments.

There is also a need to develop a more mechanistic understanding of treeline dynamics in climate change scenarios, considering variations in both, temperature and precipitation, as well as the effects of changes in soil properties and micro-topographic heterogeneity across tropical Andean treelines (Frankin et al. 2013). In addition, a further refinement would consider developing mechanistic spatial models by incorporating information on the: (a) the ecophysiological and demographic responses of woody species to abiotic drivers (e.g. soil water and nutrients, solar radiation, minium and maximum temperatures); (b) the role of biological interactions such as competition/facilitation; and (c) differences in dispersal abilities between species and life-forms (Bader et al. 2007b; Llambí et al. 2013; RamirezVillegas et al. 2014; Rehm and Feeley 2015).

\section{Conclusions}

The analysis of plant life-form distribution patterns was used in this work to link changes in vegetation physiognomy with climatic drivers influenced by topography, facilitating comparative analyses across regions with marked differences in floristic composition. Our analysis contribute novel information showing that leaf traits can play an important role in the distribution of caulescent rosettes and shrubs, improving our understanding of the underlying causes of PLF distribution patterns above the treeline. In addition, our results highlighted that the distribution of PLF in the treeline ecotone could be described by simple habitat suitability models combining the effects of elevation and slope orientation, which could, in turn, be linked with changes in temperature and incident radiation. Our habitat suitability models predicted an elevation advance of trees and a concomitant decrease in the cover of tussock grasses, caulescent rosettes and small-leaved sclerophyllous shrubs, but without the formation of closed forests above the current forest line during the next decades.

\section{Acknowledgements}

We are indebted to Mérida Cable Car System and Instituto Nacional de Parques (INPARQUES) for allowing the access to sampling sites. Thanks to A. Heredia for his assistance in fieldwork and to the journal editor Laszlo Nagy and two 
anonymous referees for their comments and suggestions, which significantly improved the manuscript.

\section{Disclosure statement}

705 No potential conflict of interest was reported by the authors.

\section{Funding}

This work was supported by the Russian Ministry of Education Post-doctoral Programme of Project '5-100'

710 [Grant № M 2.2.3] and the LEAF research network (CRN II005) financed by the Inter American Institute for Global Change Research (IAI) and coordinated by Dr Guillermo Sarmiento; Inter-American Institute for Global Change Research (IAI) [LEAF CRNII 005 project]; Russian 715 Ministry of Education [PostDoctoral Program of Project '5-100'].

\section{Notes on contributors}

Alberto Arzac is a plant ecologist. His research interest focuses on dendroclimatic studies of Eurosiberian species, quantitative wood anatomy and tree growth modelling.

Luis D. Llambí is a plant ecologist. His research focuses on the analysis of the patterns and processes influencing plant community assembly and dynamics in the high Andes.

Raphael Dulhoste is a forestry engineer. His research inter ests include the characterisation of water and temperature stress in woody species in cloud forest and grasslands.

José M. Olano is a plant ecologist. His research interests include dendroclimatic studies of Mediterranean species, quantitative wood anatomy and the evaluation of the impacts of climate change on fungi.

Eulogio Chacón-Moreno is a landscape ecologist. His research focuses on mapping and modelling vegetation and species distributions under climate change scenarios.

\section{ORCID}

Alberto Arzac (D) http://orcid.org/0000-0002-3361-5349

\section{References}

Anderson E, Marengo J, Villalba R, Halloy S, Young B, Cordero D, Gast F, Jaimes E, Ruiz D. 2011. Consequences of climate change for ecosystems and ecosystem services in the tropical Andes. In: Herzog SK, Martínez R, Jørgensen PM, Tiessen H, editors. Climate change and biodiversity in the tropical Andes. Inter-American Institute for Global Change Research; p. 1-18.
Arzac A. 2008. Distribución espacial de formas de vida de plantas en un gradiente altotérmico en Los Andes Tropicales [Bacherlor Thesis]. Universidad de los Andes.

Arzac A, Chacón-Moreno E, Llambí LD, Dulhoste R. 2011. Distribution of plant life forms in the upper limit of the forest páramo ecotone in the tropical Andes. ECOTRÓPICOS. 24:26-46.

Arzac A, García-Cervigón AI, Vicente-Serrano SM, Loidi J, Olano JM. 2016. Phenological shifts in climatic response of secondary growth allow Juniperus sabina L. to cope with altitudinal and temporal climate variability. Agric For Meteorol. 217:35-45.

Arzac A, Rozas V, Rozenberg P, Olano JM. 2018. Water availability controls Pinus pinaster xylem growth and density: A multi-proxy approach along its environmental range. Agric For Meteorol. 250-251:17-180.

Azócar A, Rada F. 2006. Ecofisiología de plantas de páramo. 1st ed ed. Mérida (Venezuela); Universidad de los Andes.

Bader MY, Rietkerk M, Bregt A. 2007a. Vegetation structure and temperature regimes of tropical alpine treelines vegetation structure and temperature regimes of tropical alpine treelines. Arct Antarct Alp Res. 39:353-364.

Bader MY, Rietkerk M, Bregt A. 2008. A simple spatial model exploring the positive feedbacks at tropical alpine treelines. Arct Antarct Alp Res. 40:269-278.

Bader MY, Ruijten JJA. 2008. A topography-based model of forest cover at the alpine tree line in the tropical Andes. J Biogeogr. 35:711-723.

Bader MY, van Geloof I, Rietkerk M. 2007b. High solar radiation hinders tree regeneration above the alpine treeline in northern Ecuador. Plant Ecolog. 191:33-45.

Báez S, Jaramillo L, Cuesta F, Donoso DA. 2016. Effects of climate change on andean biodiversity: a synthesis of studies published until 2015. Neotrop Biodivers. 2:181-194.

Balslev H, de Vries T. 1989. Life forms and species richness in a bunch grass páramo on mount cotopaxi, Ecuador. In: Erdelen W, Ishwaran N, Müller $\mathrm{P}$, editors. Proceedings of the international and interdisciplinary symposium tropical ecosystems. Weikersheim: Margraf Scientific Books; p. 45-58.

Bueno A, Llambí LD. 2015. Facilitation and edge effects influence vegetation regeneration in old-fields at the tropical Andean forest line. Appl Veg Sci. 18:613-623.

Bush MB, Hanselman JA, Gosling WD. 2010. Nonlinear climate change and Andean feedbacks: an imminent turning point? Glob Chang Biol. 16:3223-3232.

Cáceres Y, Llambí LD, Rada F. 2015. Shrubs as foundation species in a high tropical alpine ecosystem: a multi-scale analysis of plant spatial interactions. Plant Ecol Divers. 8:147-161.

Chacón-Moreno E. 2007. Ecological and spatial modeling: mapping ecosystems, landscape changes, and plant species distribution in Llanos del Orinoco, Venezuela $[\mathrm{PhD}$ Thesis]. Wageningen University.

Chacón-Moreno E, Smithk JK, Skidmore A, Prins H, Toxopeus AG. 2007. Modeling spatial patterns of plant distribution as a consequence of hydrological dynamic processes in a venezuelan flooding savanna. ECOTRÓPICOS. 20:55-73.

Chen I, Shiu H, Benedick S, Holloway JD, Khen V, Barlow HS, Hill JK, Thomas C. 2009. Elevation increases 
in moth assemblages over 42 years on a tropical mountain. Proc Natl Acad Sci. 106:1479-1483.

Cuatrecasas J. 1968. Páramo vegetation and its life forms. In: Troll C, editor. Geoecology of the mountainous regions of the tropical Americas. Proceedings of the UNESCO Mejico symposium. Bonn: Ferd Dümmlers Verlag; p. 163-186.

Deutsch CA, Tewksbury J, Huey RB, Sheldon KS, Ghalambor CK, Haak DC, Martin PR. 2008. Impacts of climate warming on terrestrial ectotherms across latitude. Proc Natl Acad Sci. 105:6668-6672.

Dirnböck T, Dullinger S, Grabherr G. 2003. A regional impact assessment of climate and land-use change on alpine vegetation. J Biogeogr. 30:401-417.

820 Duque A, Stevenson PR, Feleey KJ. 2015. Thermophilization of adult and juvenile tree communities in the northern tropical Andes. Proc Natl Acad Sci. 112(34):10744-10749.

Ely F, Torres F. 2003. Adaptaciones antómico-estructurales foliares de Chaetolepis lindeniana (Naud.) Triana a lo largo de un gradiente altitudinal en el Páramo del Parque Nacional Sierra Nevada de Mérida (Venezuela). Plantula. 3:101-115.

Fadrique B, Báez S, Duque Á, Malizia A, Blundo C, 830 Carilla J, Osinaga-Acosta O, Malizia L, Silman M, Farfán-Ríos W, et al. 2018. Widespread but heterogeneous responses of Andean forests to climate change. Nature. 564:207-212.

Feeley K. 2012. Distributional migrations, expansions, and contractions of tropical plant species as revealed in dated herbarium records. Glob Chang Biol. 18:1335-1341.

Feeley K, Silman MR. 2010. Land-use and climate change effects on population size and extinction risk of Andean plants. Glob Chang Biol. 16:3215-3222.

840 Feeley K, Silman MR, Bush MB, Farfan W, Garcia Cabrera KG Malhi Y, Meir P, Salinas Revilla N, Raurau Quisiyupanqui MNR Saatchi S. 2011. Upslope migration of Andean trees. J Biogeogr. 38:783-791.

Frankin J, Davis FW, Ikegami M, Syphard AD, Flint LE, Flint AL, Hannah L. 2013. Modeling plant species distributions under future climates: how fine scale do climate projections need to be? Glob Chang Biol. 19:473-483.

Furze JN, Zhu Q, Qiao F, Hill J. 2013. Functional enrichment of utopian distribution of plant life-forms. Am J Plant Sci. 4:37-48.

García-Cervigón AI, Olano JM, Eugenio M, Camarero JJ. 2012. Arboreal and prostrate conifers coexisting in mediterranean high mountains differ in their climatic responses. Dendrochronologia. 30:279-286.

García-Varela S, Rada F. 2003. Freezing avoidance mechanisms in juveniles of giant rosette plants of the genus Espeletia. Acta Oecol. 24:165-167.

González W, Llambí LD, Smith JK, Gámez LE. 2011.

860 Dinámica sucesional del componente arbóreo en la zona de transición bosque-Páramo en Los Andes tropicales. Ecotropicos. 24:60-79.

Greig-Smith P. 1983. Plant ecology. 3rd ed. Barkeley and Los Angeles (USA): University of California Press.

865 Guisan A, Zimmermann NE. 2000. Predictive habitat distribution models in ecology. Ecol Modell. 135:147-186.
Harden CP, Hartsig J, Farley KA, Lee J, Bremer LL. 2013. Effects of land-use change on water in Andean Páramo grassland soils. Ann Am Assoc Geogr. 103:375-384.

Hedberg I, Hedberg O. 1979. Tropical-alpine life-forms of vascular plants. Oikos. 33:297-307.

Hedberg O. 1964. Features of afroalpine plant ecology. Acta Phytogeogr Suecica. 49:1-144.

Hofstede RGM, Dickinson KJM, Mark A, Narváez E. 2014. A broad transition from cloud forest to páramo characterizes an undisturbed treeline in parque nacional llanganates, Ecuador. Arct Antarct Alp Res. 46:975-986.

Holtmeier FK. 2009. Mountain timberlines. Ecology, patchiness, and dynamics. Springer.

Holtmeier FK, Broll G. 2005. Sensitivity and response of northern hemisphere altitudinal and polar treelines to environmental change at landscape and local scales. Global Ecol Biogeogr. 14:395-410.

Hribljan JA, Suarez E, Bourgeau-Chavez L, Endres S, Lilleskov EA, Chimbolema S, Wayson C, Serocki E, Chimner RA. 2017. Multi-date, multi-sensor remote sensing reveals high density of carbon-rich mountain peatlands in the páramo of Ecuador. Glob Chang Biol. 23:5412-5425.

Hribljan JA, Suarez E, Katherine H, Lilleskov E, Chimner RA. 2016. Peatland carbon stocks and accumulation rates in the ecuadorian páramo. Wetlands Ecol Manage. 24:113-127.

IPCC. 2013. The physical science basis. contribution of working group $\mathrm{i}$ to the fifth assessment report of the intergovernmental panel on climate change. Cambridge (United Kingdom) and New York (USA):IPCC.

ITC-ILWIS. 2001. Ilwis 3.0 User's Guide: ITC

Keating P. 1999. Changes in páramo vegetation along an elevation gradient in southern Ecuador. J Torrey Bot Soc. 126:159-175.

Körner C. 2012. Alpine treelines. Functional ecology of the global high elevation tree limits. 1st ed. Basel: Springer.

Legendre P, Legendre L. 2012. Numerical ecology. 2nd ed. Amsterdam: Elsevier.

Llambí LD. 2015. Estructura, diversidad y dinámica de la vegetación en el ecotono bosque-páramo: revisión de la evidencia en la Cordillera de Mérida. Acta Biolo Colomb. 20:5-20.

Llambí LD, Ramírez L, Schwarzkopf T. 2014. Patrones de distribución de plantas leñosas en el ecotono bosquepáramo de la Sierra Nevada de Mérida: ¿Qué nos sugieren sobre la dinámica del límite del bosque?. In: Cuesta F, Sevink J, Llambí LD, De Bièvre B, Posner J, editors. Avances en investigación para la conservación de los páramos andinos. Lima (Peru): CONDESAN.

Llambí LD, Sarmiento L, Rada F. 2013. Evolución de la Investigación Ecológica en los Páramos de Venezuela: múltiples visiones de un ecosistema único. In: Medina M, Hubber O, Nassar J, Navarro P, editors. Recorriendo el Paisaje Vegetal de Venezuela. Carcas (Venrzuela): IVIC; p. 173-209.

Lutz DA, Powell RL, Silman MR. 2013. Four decades of Andean timberline migration and implications for biodiversity loss with climate change. PLoS One. 8:e74496.

Mathez-Stiefel SL, Peralvo M, Báez S, Riest S, Buytaert W, Cuesta F, Fadrique B, Feeley KJ, Groth AA, Homeir J, 
et al. 2017. Research priorities for the conservation and sustainable governance of Andean forest landscapes. $\mathrm{Mt}$ Res Dev. 37(3):323-339.

Meinzer F, Goldstein G, Rada F. 1994. Páramo microclimate and leaf thermal balance of Andean giant rosette plants. In: Rundel P, Smith A, Meinzer F, editors. Tropical alpine environments: plant form and function.

935 Cambridge (United kingdom): Cambridge University Press; p. 45-59.

Molina A, Vanacker V, Brisson E, Mora D, Balthazar V. 2015. Long-term effects of climate and land cover change on freshwater provision in the tropical Andes. Hydrol Earth Syst Sci. 12:5219-5250.

Morueta-Holme N, Engemann K, Sandoval-Acuña P, Jonas JD, Segnit RM, Svennin J-C. 2015. Strong upslope shifts in Chimborazo's vegetation over two centuries since humboldt. Proc Natl Acad Sci U S A. 112:12741-12745.

Myers N, Mittermeier RA, Mittermeier CG, Da Fonseca GAB, Kent J. 2000. Biodiversity hotspots for conservation priorities. Nature. 403:853-858.

Peters T, Braeuning A, Muenchow J, Richter M. 2014. An ecological paradox: high species diversity and low position of the upper forest line in the Andean depression. Ecol Evol. 4:2134-2145.

Price M. 2003. Why mountain forests are important. For Chron. 79:219-222.

955 Rada F, Goldstein G, Azocar A, Meinzer F. 1985. Freezing avoidance in Andean giant rosette plants. Plant Cell Environ. 8:501-507.

Ramírez L, Llambí LD, Scharrzkopf T, Gámez LE, Márquez NJ. 2009. Vegetation structure alnog the forestpáramo transition belt in the Sierra Nevada de Mérida: implications for understanding the treeline dynamics. ECOTRÓPICOS. 22:83.

Ramírez L, Rada F, Llambí LD. 2015. Linking patterns and processes through ecosystem engineering: effects of shrubs on microhabitat and water status of associated plants in the high tropical Andes. Plant Ecolog. 216:213-225.

Ramirez-Villegas J, Cuesta F, Devenish C, Peralvo M, Jarvis A, Arnillas CA. 2014. Using species distributions models for designing conservation strategies of tropical Andean biodiversity under climate change. J Nat Conserv. 22:391-404.

Ramsay P, Oxley E. 1997. The growth form composition of plant communities in the ecuadorian páramos. Plant Ecolog. 131:173-192.

Rehm EM, Feeley KJ. 2013. Forest patches and the upward migration of timberline in the southern peruvian Andes. For Ecol Manage. 305:204-211.

Rehm EM, Feeley KJ. 2015. The inability of tropical cloud 980 forest species to invade grasslands above treeline during climate change: potential explanations and consequences. Ecography. 38:1167-1175.

Rehm EM, Feeley KJ, Meinzer FC. 2015. Freezing temperatures as a limit to forest recruitment above tropical Andean treelines. Ecology. 96:1856-1865.

Santaella W. 2007. Análisis del cambio del paisaje en la línea transicional páramo-selva nublada, sector La
Aguada de la vertiente norte de la Sierra Nevada de Mérida [Bachelor Thesis]. Universidad de Yacambú

Sarmiento Pinzón CE, León Moya OA. editors. 2015. Transición bosque-páramo. Bases con-ceptuales y métodos para su identificación en los Andes colombianos. Bogota: Instituto de Investigación de Recursos Biológicos Alexander von Humboldt.

Scherrer D, Körner S. 2011. Topographically controlled thermal-habitat differentiation buffers alpine plant diversity against climate warming. J Biogeogr. 38:406-416.

Sklenár P, Jørgensen PM. 1999. Distribution patterns of páramo plants in Ecuador. J Biogeogr. 26:681-691.

Squeo F, Rada F, Azócar A, Goldstein G. 1991. Freezing tolerance and avoidance in high tropical Andean plants: Is it equally represented in species with different plant height? Oecologia. 86:378-382.

Suárez del Moral P, Chacón-Moreno E. 2011. Modelo espacial de distribución el ecotono bosque-páramo en los Andes Venezolanos. Ubicación potencial y escenarios de cambio climático. ECOTRÓPICOS. 24:3-25.

Swenson JJ, Young BE, Beck S, Comer P, Córdova JH, Dyson J, Embert D, Encarnación F, Ferreira W, Franke I, et al. 2012. Plant and animal endemism in the eastern Andean slope: challenges to conservation. BMC Ecol. 12:1.

Tovar C, Arnillas CA, Cuesta F, Buytaert W. 2013. Diverging responses of tropical Andean biomes under future climate conditions. PLoS One. 8:e63634.

Vareschi W. 1992. Ecología de la vegetación tropical. Caracas (Venezuela): Sociedad Venezolana de Ciencias Naturales.

Vuille M, Bradley R. 2000. Mean temperature trends and their vertical structure in the tropical Andes. Geophys Res Lett. 27:3885-3888.

Vuille M, Carey M, Huggel C, Buytaert W, Rabatel A, Jacobsen D, Soruco A, Villacis M, Yarleque C, Elison Timm O, et al. 2018. Rapid decline of snow and ice in the tropical Andes - impacts, uncertainties and challenges ahead. Earth Sci Rev. 176:195-213.

Wille M, Hooghiemstra H, Hofstede R, Feshe J, Sevink J. 2002. Upper forest line reconstruction in a deforested area in northern Ecuador based on pollen and vegetation analysis. J Trop Ecol. 18:409-440.

Williams JH, Jackson ST. 2007. Novel climates, no-analog communities, and ecological surprises. Front Ecol Environ. 5:475-482.

Wolfe JA. 1979. Temperature parameters of humid to mesic forests of Eastern Asia and relation to forests of other regions of the Northern hemisphere and Australasia. Vol. 1106, U.S. Geological Survey Professional Paper. p. 1-37.

Young KR. 2009. Andean land use and biodiversity: humanized landscapes in a time of change. Ann Mo Bot Gard. 96:492-507.

Young KR, León B. 2007. Treeline changes along the Andes: implications of spatial patterns and dynamics. Philos Trans R Soc Biol Sci. 362:263-272.

Young KR, Ulloa Ulloa C, Luteyn JL, Knapp S. 2002. Plant evolution and endemism in Andean South America: an introduction. Bot Rev. 68:4-21.

990 